\title{
Soil Test Based Fertilizer Recommendation for Targeted Yield of French Bean (Phaseolus vulgaris) under Rice-French Bean Cropping System
}

\author{
Sowmya Pogula ${ }^{1}$, Truptimayee ${ }^{1}$, Antaryami Mishra ${ }^{1 *}$, Subhashis Saren ${ }^{1}$ and P. Dey ${ }^{2}$ \\ ${ }^{1}$ Orissa University of Agricultural Chemistry, Bhubaneswar, Orissa (751 003), India \\ ${ }^{2}$ Indian Institute of Soil Science, Bhopal, Madhya Pradesh (462 038), India
}

\section{Article History}

Manuscript No. AR1536

Received in $8^{\text {th }}$ February, 2016

Received in revised form $15^{\text {th }}$ September, 2016

Accepted in final form $27^{\text {th }}$ September, 2016

\section{Correspondence to}

*E-mail: saren.soil@yahoo.co.in

\section{Keywords}

French bean, targeted yield, fertilizer

prescription equations

\begin{abstract}
A field experiment was conducted during 2014-2015 to study the response of French bean (Phaseolus vulgaris) to graded doses of fertilizer and to formulate soil test based fertilizer recommendation for targeted yield of french bean under ricefrench bean cropping system in a lateritic soils of Odisha. Detailed morphological and physico-chemical properties of a typifying pedon of the experimental site was conducted. In kharif season, three fertility gradient strips were created (B-I, B-II \& B-III) by application of no fertilizer, recommended dose of fertilizer and twice of the recommended dose in rice. Each of these fertility gradient strips were divided into 24 sub-plots where 21 plots were treated with different treatment combinations of $\mathrm{N}, \mathrm{P}$ and $\mathrm{K}$, two plots received 2.5 and $5.0 \mathrm{t} \mathrm{ha}^{-1}$ and one plot was kept as absolute control. French bean (cv. Anupam) was grown in these sub-plotsfor investigation during rabi. Highest pod yield, uptake of N, P and K of french bean was achieved in B-III block. Mean pod yield varies from 57.6 to $75.0 \mathrm{q} \mathrm{ha}^{-1}$ whereas, uptake of $\mathrm{N}, \mathrm{P}$ and $\mathrm{K}$ vary from 67.9 to $75.0,49.0$ to 56.6 and 69.9 to $84.9 \mathrm{~kg} \mathrm{ha}^{-1}$ respectively. Targeted yield equations for french bean were developed using the Ramamoorthy's targeted yield approach for site specific integrated nutrient management.
\end{abstract}

\section{Introduction}

The french bean (Phaseolus vulgaris L.) is one of the most important leguminous vegetables. It is the World's most important food legume. It is also called as common bean, kidney bean, haricot bean, snap bean and navy bean.

Fertilizer is one of the most important agriculture inputs for increasing the crop production. Soil testing is now accepted as a basis for the recommendation of the fertilizer doses for various crops in India. But soil testing would become a useful tool only when it is based on intimate knowledge of soilcrop-variety fertilizer climate management interaction for a given situation (Kanwar, 1971). The fertilizer application by the farmers in the field without knowledge of soil fertility status and nutrient requirement of different crops usually leads to adverse effect on soil as well as crops by way of nutrient deficiency or toxicity due to over use or inadequate use of fertilizers. In this regard, targeted yield approach has been found to be beneficial which recommends balanced fertilization considering available nutrient status, in the soil and the crop needs. The concept of fertilizer prescription equation for desire yield was first given by Troug (1960).
Ramamoorthy et al. (1967) established the theoretical basis and experimental technique to suit it to Indian conditions. They showed that the linear relationship between yield of grain and nutrient uptake. For obtaining a given yield, fertilizer requirement can be estimated considering efficiency of soil and fertilizer nutrients.

Though fertilizer prescription equations have been developed for targeted yields of different vegetable crops of Odisha like pumpkin (Gogoi et al., 2011), lady’s finger (Mishra et al., 2013), tomato (Mishra et al., 2013), brinjal (Mishra et al., 2013) and chilli (Mishra et al., 2014) which are applicable for crops grown in red and laterite soils of the state, no such equation has yet been developed for french bean (Phaseolus vulgaris) crop for our condition. Therefore an attempt has been made in the present investigation to find out a fertilizer prescription equations for french bean under rice-french bean cropping system in lateritic soils of Odisha.

\section{Materials and Methods}

The field experiment was conducted during 2014-2015 tunder rice-french bean cropping system in a lateritic soils 
of Odisha. The experimental site was a medium and the texture of both surface and sub-surface soil was sandy loam. The soil was moderately acidic $(\mathrm{pH} 5.39)$ in reaction and medium in OC $\left(5.8 \mathrm{~g} \mathrm{~kg}^{-1}\right)$. CEC of the surface soil was 4.5 $\mathrm{Cmol}\left(\mathrm{P}^{+}\right) \mathrm{kg}^{-1}$ with $65.11 \%$ base saturation. The soils of the experimental site were classified as fine, mixed, hyperthermic family of Vertic Haplustepts.

The experiment site ( $0.3 \mathrm{ha}$ ) was divided in to 3 equal blocks during kharif to create fertility gradient strips and rice (cv. Lalat) was transplanted with application of $25 \%$ dose of N, full dose of $\mathrm{P}$ and $\mathrm{K}$ during last week of July at the rate of $\mathrm{N}_{0} \mathrm{P}_{0} \mathrm{~K}_{0}$ in Block-I; $\mathrm{N}_{80} \mathrm{P}_{40} \mathrm{~K}_{40}$ (recommended dose) in BlockII and $\mathrm{N}_{160} \mathrm{P}_{80} \mathrm{~K}_{80}$ (twice of the recommended dose) in BlockIII. Soil samples were collected along with grain and straw samples at harvest for chemical analysis based on the methods laid down by Jackson (1973).

The three Blocks (B-I, B-II and B-III) were ploughed and each Block was sub-divided into 24 subplots $\left(5.5 \times 4 \mathrm{~m}^{2}\right.$ each). Initial soil fertility status of each sub-plot was recorded. Twenty one sub-plots were treated with different treatment combinations of NPK fertilizer, two plots were applied FYM at 2.5 and $5 \mathrm{t} \mathrm{ha}^{-1}$ and one plot was kept as absolute control and french bean (cv. Anupam) was grown during rabi. The parameters needed for formulating fertilizer prescription equation for targeted yields were experimentally obtained for a given soil type crop agro climatic condition. These parameters are nutrient requirement/removed (NR) in $\mathrm{kg} \mathrm{q}^{-1}$ of economic produce (grain/fruit/other economic part).

$$
\mathrm{NR}\left(\mathrm{kg} \mathrm{q}^{-1}\right)=\frac{\text { Uptake of nutrient }(\mathrm{kg})}{\text { Yield in }\left(\mathrm{q} \mathrm{ha}^{-1}\right)}
$$

The per cent contribution from soil available nutrient (Cs)

$$
\mathrm{Cs}=\frac{\text { Total uptake in absolute control plot }\left(\mathrm{kg} \mathrm{ha}^{-1}\right)}{\text { Soil test value of nutrients in control plot }\left(\mathrm{kg} \mathrm{ha}^{-1}\right)}
$$

The per cent contribution from applied fertilizer nutrient (Cf)

$$
\mathrm{Cf}=\frac{\text { Total uptake in treated plot-soil test value }(\mathrm{STV}) \times \mathrm{Cs}}{\text { Fertilizer applied }\left(\mathrm{kg} \mathrm{ha}^{-1}\right)}
$$

These parameters were then transformed to a workable equation as follows

$$
\mathrm{FD}=\frac{(\mathrm{NR} \times 100 \times \mathrm{T})}{\mathrm{Cf}}-\frac{\mathrm{Cs}}{\mathrm{Cf}} \times \mathrm{STV}
$$

Where, $\mathrm{FD}=$ Fertilizer dose, $\mathrm{T}=$ Yield target $\left(\mathrm{q} \mathrm{ha}^{-1}\right), \mathrm{STV}=$ Soil test value

\section{Results and Discussion}

The range and average of initial soil test values, uptake of nutrients and grain yield of french bean are presented in (Table 1). The mean value of soil available N, P and K increases with increase in fertility gradient strip from B-I to B-III. The mean value of available $\mathrm{N}$ ranges between 129.0

\begin{tabular}{|c|c|c|c|c|}
\hline \multirow[t]{2}{*}{ Particulars } & & \multicolumn{3}{|c|}{ Fertility gradient strips } \\
\hline & & B-I & B-II & B-III \\
\hline \multirow{2}{*}{$\begin{array}{l}\text { Grain } \\
\text { yield } \\
\left.(\mathrm{q} \mathrm{ha})^{-1}\right)\end{array}$} & Range & $32.7-73.4$ & $54.9-87.5$ & $59.0-91.5$ \\
\hline & Average & 57.67 & 73.40 & 75.00 \\
\hline \multirow[t]{2}{*}{$\begin{array}{l}\text { Available } \\
\mathrm{N}\left(\mathrm{kg} \mathrm{ha}^{-1}\right)\end{array}$} & Range & $113-129.2$ & $\begin{array}{c}130.8- \\
146\end{array}$ & $\begin{array}{c}147.4- \\
156.3\end{array}$ \\
\hline & Average & 129.0 & 140.2 & 149.3 \\
\hline \multirow{2}{*}{$\begin{array}{l}\text { Available } \\
\mathrm{P}\left(\mathrm{kg} \mathrm{ha}^{-1}\right)\end{array}$} & Range & $32.2-38.8$ & $39.6-48.8$ & $44.8-57.3$ \\
\hline & Average & 34.8 & 44.7 & 53.3 \\
\hline \multirow[t]{2}{*}{$\begin{array}{l}\text { Available } \\
\mathrm{K}\left(\mathrm{kg} \mathrm{ha}^{-1}\right)\end{array}$} & Range & $\begin{array}{c}110.2- \\
127.6\end{array}$ & $\begin{array}{c}119.5- \\
129.4\end{array}$ & $\begin{array}{c}122.8- \\
150.1\end{array}$ \\
\hline & Average & 120.5 & 126.2 & 135.7 \\
\hline \multirow{2}{*}{$\begin{array}{l}\text { N uptake } \\
\left(\mathrm{kg} \mathrm{ha}^{-1}\right)\end{array}$} & Range & $30.0-82.3$ & $40.2-85.5$ & $50.0-88.0$ \\
\hline & Average & 67.9 & 72.4 & 75.0 \\
\hline \multirow{2}{*}{$\begin{array}{l}\text { P uptake } \\
\left(\mathrm{kg} \mathrm{ha}^{-1}\right)\end{array}$} & Range & $31.8-58.8$ & $43.1-61.5$ & $49.2-66.6$ \\
\hline & Average & 49.0 & 53.3 & 56.6 \\
\hline \multirow[t]{2}{*}{$\begin{array}{l}\text { K uptake } \\
\left(\mathrm{kg} \mathrm{ha}^{-1}\right)\end{array}$} & Range & $51.1-87.3$ & $\begin{array}{l}59.0- \\
101.7\end{array}$ & $\begin{array}{l}62.5- \\
109.2\end{array}$ \\
\hline & Average & 69.9 & 80.9 & 84.9 \\
\hline
\end{tabular}
to $149.3 \mathrm{~kg} \mathrm{ha}^{-1}$; that of $\mathrm{P}$ (Bray's $\mathrm{P}$ ) ranges from 34.8 to 53.3

Table 1: Range and average yield of French bean (cv. Anupam), soil test values and NPK total uptake in different fertility gradient strips

$\mathrm{kg} \mathrm{ha}^{-1}$ and $\mathrm{K}$ ranges between 120.5 to $135.7 \mathrm{~kg} \mathrm{ha}^{-1}$. Thus the experimental site is low in soil available $\mathrm{N}$, medium in available $\mathrm{P}$ and low in available $\mathrm{K}$. The uptake of $\mathrm{N}$, $\mathrm{P}$, and $\mathrm{K}$ shows an increasing trend with increasing in fertility gradient strips from B-I to B-III. The average uptake of N in B-I is $67.9 \mathrm{~kg} \mathrm{ha}^{-1}$ which increases to $75.0 \mathrm{~kg} \mathrm{ha}^{-1}$ in B-III. Similarly the average uptake of P ranges from 49.0 in B-I to $56.6 \mathrm{~kg}$ $\mathrm{ha}^{-1}$ in B-III. The average uptake of $\mathrm{K}$ follows a similar trend which ranges from $69.9 \mathrm{~kg}$ in B-I to $84.9 \mathrm{~kg} \mathrm{ha}^{-1}$ in B-III. The uptake of nutrient co-relates well with yield of french bean. Result shows that higher the N, P, K uptake higher is the yield of french bean. The average yield of french bean ranges from $57.67 \mathrm{q} \mathrm{ha}^{-1}$ in the lowest fertility gradient strip (B-I) to $75.0 \mathrm{q} \mathrm{ha}^{-1}$ in the highest fertility gradient strip (B-III). It was observed that with increase in graded doses of fertilizer the french bean grain yield increased with increase in the fertility gradient strips (B-I, B-II and B-III respectively). Soil test based fertilizer prescription equations for targeted yield of french bean were formulated using the basic parameters from the data of soil test value, yield of french bean and 
uptake of nutrients (Table 2). On the basis of these fertilizer prescription equations, ready reckoner was prepared for a range of soils test values and french bean grain yield targets of 60-90 q ha ${ }^{-1}$ (Table 3). Fertilizer requirement is increased with increase of the desired yield target and decreased with

Table 2: The fertilizer prescription equation developed for french bean

\begin{tabular}{lcccc}
\hline Parameters & $\mathrm{N}$ & $\mathrm{P}_{2} \mathrm{O}_{5}$ & $\mathrm{~K}_{2} \mathrm{O}$ & Targeted yield equations \\
\hline $\mathrm{NR}\left(\mathrm{kg} \mathrm{q}^{-1}\right)$ & 0.3 & 0.7 & 1.3 & $\mathrm{FN}=1.6 \mathrm{~T}-0.5 \mathrm{SN}$ \\
$\mathrm{Cs}(\%)$ & 10 & 24 & 20 & $\mathrm{FP}_{2} \mathrm{O}_{5}=1.5 \mathrm{~T}-1 \mathrm{SP}_{2} \mathrm{O}_{5}$ \\
$\mathrm{Cf}(\%)$ & 20 & 30 & 44 & $\mathrm{~F} \mathrm{~K}_{2} \mathrm{O}=3 \mathrm{~T}-1.1 \mathrm{~K}_{2} \mathrm{O}$ \\
\hline
\end{tabular}

the higher soil test values. The multiple regression equation of interaction of different factors (soil nutrient, uptake and fertilizer doses) is presented in (Table 4). Multiple regression

Table 3: Prescribed fertilizer doses of french bean based on targeted yield concept

\begin{tabular}{|c|c|c|c|c|}
\hline $\begin{array}{l}{ }^{*} \mathrm{I} . \mathrm{S} \quad \mathrm{N}: \\
\mathrm{P}_{2} \mathrm{O}_{5}: \mathrm{K}_{2} \mathrm{O}\end{array}$ & $\begin{array}{c}60 \\
\left(\mathrm{q} \mathrm{ha} \mathrm{a}^{-1}\right)\end{array}$ & $\begin{array}{c}70 \\
\left(\mathrm{q} \mathrm{ha} \mathrm{a}^{-1}\right)\end{array}$ & $\begin{array}{c}80 \\
\left(\mathrm{q} \mathrm{ha} \mathrm{a}^{-1}\right)\end{array}$ & $\begin{array}{c}90 \\
(\mathrm{q} \mathrm{ha-1})\end{array}$ \\
\hline $80: 20: 100$ & $37: 63: 66$ & 53:78:93 & $69: 93: 124$ & $85: 108: 154$ \\
\hline $100: 25: 110$ & $27: 58: 53$ & $43: 73: 83$ & $59: 88: 113$ & $75: 103: 143$ \\
\hline $120: 30: 120$ & $15: 53: 43$ & $33: 68: 73$ & $49: 83: 102$ & $65: 98: 132$ \\
\hline $140: 35: 130$ & $15: 48: 30$ & $23: 63: 63$ & $39: 78: 91$ & $55: 93: 121$ \\
\hline $160: 40: 150$ & $15: 43: 20$ & $15: 58: 38$ & $29: 73: 69$ & $45: 88: 99$ \\
\hline $180: 45: 170$ & $15: 38: 20$ & $15: 53: 20$ & $19: 68: 47$ & $35: 83: 77$ \\
\hline 200:50:190 & $15: 33: 20$ & $15: 48: 20$ & $15: 63: 25$ & $25: 78: 55$ \\
\hline $210: 55: 200$ & $15: 28: 20$ & $15: 43: 20$ & $15: 58: 20$ & $19: 73: 46$ \\
\hline $220: 60: 210$ & $15: 23: 20$ & $15: 38: 20$ & $15: 53: 20$ & $15: 68: 33$ \\
\hline
\end{tabular}

*I.S: Initial status

equation of the average yield of the four fertility gradient strips with respect to initial soil nutrient (N, P and K), uptake of nutrients and applied fertilizer dose were calibrated. It is obvious from the equation from the equation that initial soil phosphorus, uptake of potassium and fertilizer nitrogen made

Table 4: Multiple regression equations

$\mathrm{Y}=-70.239+0.247 \mathrm{SN}+2.282 \mathrm{SP}^{* *}+0.055 \mathrm{SK}$

$0.435^{* *}$

$\mathrm{Y}=14.725+0.131 \mathrm{UN}+0.058 \mathrm{UP}+0.572^{* *} \mathrm{UK} \quad 0.918^{* *}$

$\mathrm{Y}=55.47+0.159 \mathrm{FN}^{*}+0.072 \mathrm{FP}+0.078 \mathrm{FK} \quad 0.691^{* *}$

$\mathrm{Y}=64.06+0.33 \mathrm{SN}+0.09 \mathrm{SP}+0.02 \mathrm{SK}+0.02 \mathrm{UN}+\quad 0.976^{* *}$

$0.07 \mathrm{UP}+0.79 \mathrm{UK}^{* *}+0.02 \mathrm{FN}+0.04 \mathrm{FP}+0.04 \mathrm{FK}$

Where Y, SN, SP, SK, UN, UP, UK, FN, FP and FK represented in $\mathrm{kg} \mathrm{ha}^{-1}$, the pod yields, initial soil value (i.e., $\mathrm{N}, \mathrm{P}$ and $\mathrm{K}$ ), uptake of nutrients and applied fertilizer dose $(\mathrm{N}, \mathrm{P}, \mathrm{K})$ significant contribution towards the pod yield of french bean.

\section{Conclusion}

By using the fertilizer prescription equations, if initial soil test values are known then we can prescribe fertilizer dose for targeting specific yield of french bean which is superior to blanket application for specific yield target will not only maintain soil health for sustainable crop production but it will also enable the farmers to reduce the use of costly fertilizer input depending on financial condition of the farmers of Odisha.

\section{References}

Gogoi, A., Mishra, A., Jena, B., 2011. Soil test based fertilizer recommendation for targeted yield of pumpkin (Cucurbita moschata) under rice-pumpkin cropping system in an inceptisol of Odisha, Environment \& Ecology 29(2), 574-576.

Jackson, M.L., 1973. Soil chemical analysis. Prentice Hall of India Pvt. Ltd., New Delhi, India, 521.

Kanwar, J.S., 1971. Soil testing service in India retrospect and prospect. In: Proceeding of International Symposium on soil fertility evaluation, New Delhi, 1103-1113.

Mishra, A., Saren, S., Das, D., Dey, P., 2014. Soil test based fertilizer recommendation for targeted yield of chilli under rice-chilli cropping system in an inceptisol of Orissa, Indian Agriculturist 58(1), 19-24.

Mishra, A., Dash, B.B., Nanda, S.K., Das, D., 2013. Soil test based fertilizer recommendation for targeted yield of lady's finger (Abelmoschus esculentus) under ricelady's finger cropping system in an ustochrept of Orissa. Environment \& Ecology 31(1), 58-61.

Mishra, A., Dash, B.B, Nanda, S.K., Das, D., Dey, P., 2013. Soil test based fertilizer recommendation for targeted yield of tomato (Lycopersicon esculentum) under ricetomato cropping system in an ustochrept of Odisha. Environment \& Ecology 31(2A), 655-658.

Mishra, A., Das, D., Saren, S., 2013. Soil test based fertilizer recommendation for targeted yield of Brinjal (Solanum melongena) under rice-brinjal cropping system in an inceptisol of Odisha. Odisha Horticulture 2(2), 62-69.

Ramamoorthy, B., Narsimhan, R.L., Dinesh, R.S., 1967. Fertilizer application for specific yield targets of Sonora-64. Indian Farming 25(5), 43.

Troug, E., 1960. Fifty years of Soil Testing. In: $7^{\text {th }}$ Intl. Cong. Soil Sc., Wisconsin, USA, 36-45. 